\title{
Survey of molds, yeast and Alicyclobacillus spp. from a concentrated apple juice productive process
}

\author{
Beatriz de Cássia Martins Salomão ${ }^{1}$, Chalana Muller², Hudson Couto do Amparo ${ }^{2}$, \\ Gláucia Maria Falcão de Aragão ${ }^{3}$ \\ ${ }^{1}$ Departamento de Engenharia Química, Universidade Federal do Rio Grande do Norte, Natal, RN, Brazil. \\ ${ }^{2}$ Núcleo de Biotecnologia, Universidade do Oeste de Santa Catarina, Videira, SC, Brazil. \\ ${ }^{3}$ Departamento de Engenharia Química e Engenharia de Alimentos, \\ Universidade Federal de Santa Catarina, Florianópolis, SC, Brazil.
}

Submitted: July 4, 2012; Approved: September 9, 2013.

\begin{abstract}
Bacteria and molds may spoil and/or contaminate apple juice either by direct microbial action or indirectly by the uptake of metabolites as off-flavours and toxins. Some of these microorganisms and/or metabolites may remain in the food even after extensive procedures. This study aim to identify the presence of molds (including heat resistant species) and Alicyclobacillus spp., during concentrated apple juice processing. Molds were isolated at different steps and then identified by their macroscopic and microscopic characteristics after cultivation on standard media at 5, 25 and $37^{\circ} \mathrm{C}$, during 7 days. Among the 19 isolated found, $63 \%$ were identified as Penicillium with $50 \%$ belonging to the $P$. expansum specie. With regards to heat resistant molds, the species Neosartorya fischeri, Byssochlamys fulva and also the genus Eupenicillium sp., Talaromyces sp. and Eurotium sp. were isolated. The thermoacidophilic spore-forming bacteria were identified as $A$. acidoterrestris by a further investigation based on 16S rRNA sequence similarity. The large contamination found indicates the need for methods to eliminate or prevent the presence of these microorganisms in the processing plants in order to avoid both spoilage of apple juice and toxin production.
\end{abstract}

Key words: concentrated apple juice, Alicyclobacillus acidoterrestris, heat resistant mold, Penicillium expansum.

\section{Introduction}

Apple juice belongs to the most frequently consumed types of fruit juices worldwide (53). The necessity to implement and optimize fast and efficient methods for quality control appears as a consequence of this use, and should be done throughout the whole processing procedure, beginning in the orchard (Silva et al., 1997).

Some species of molds may cause serious postharvest diseases in apples (Kupferman 1986). Among them, Penicillium expansum is reported as being responsible for major decay on apples. Studies have shown that this mold is found in soil, on plant surfaces, in dump tank or flume water (Spotts and Cervantes, 1993), in contaminated wooden bins (Sanderson and Spotts, 1995) and in the atmosphere (Amiri and Bompeix, 2005). Furthermore, this mold has the ability to produce patulin (Doores, 1983), a mycotoxin reported to cause oxidative damage to the DNA in human cells, which plays a role in mutagenesis and cancer initiation (Liu et al., 2003).

Heat resistant molds (HRM) are among the microorganisms of great importance in the spoilage of heat-processed fruit juices, such as apple juice. Representative species are found in the genera Byssochlamys, Neosartorya, Eupenicillium, Talaromyces, (Murakami et al., 1998; Suresh et al., 1996; Tournas, 1994) Eurotium (Splittstoesser et al., 1989; Yildiz and Coksoyler, 2002) and Paecilomyces (Peña et al., 2004; Piecková and Sam- 
son, 2000). Some of the heat resistant molds can cause both spoilage of fruit products and produce toxic and sometimes carcinogenic compounds (Tournas, 1994; Ugwuanyi and Obeta, 1999).

Alicyclobacillus acidoterrestris is a thermoacidophilic spore-forming bacterium (ATSB) which is able to spoil acidic juices (Bahçeci and Acar, 2007; Chen et al., 2006; Eguchi et al., 1999; Groenewald et al., 2009; McKnight et al., 2010; Yamazaki et al., 1996). Spoilage by Alicyclobacillus has become a problem for the apple juice industry and effective solutions should be found to control its development. The spoilage generally is manifested as an off-flavour and an off-odour of a medicinal or chemical nature due to the formation of guaiacol and halophenols (Chang and Kang, 2004; Chen et al., 2006; Yamazaki et al., 1996), leading to consumer rejections (Zierler et al., 2004).

Apples rejected by the rigid selection criteria for the fresh fruit consumption market are used for juice processing. Microorganisms mentioned above may be present leading to a health risk for consumers and/or high economic losses due to juice deterioration. This study aims to survey molds (including heat resistant ones), yeast and Alicyclobacillus spp. in a concentrated apple juice manufacturing process.

\section{Materials and Methods}

\section{Sampling}

Samples were obtained at different stages from a concentrated apple juice processing plant in Brazil. The samples (collected in the off-season period) were taken at the following steps: apples in the reception (A); washed apples (WA); wash water (W) (recycled in a close system); must (M); bagasse (B); before pre-concentration (BPC); after pre-concentration (APC); enzymatic treatment (ET); before ultra-filtration (BUF); after ultra-filtration (AUF); before concentration (BC); after concentration (AC) and final product (FP). All samples were collected (approximately $250 \mathrm{~mL}$ per step) in sterile sampling containers, on the same day. Then they were stored under refrigeration using reusable ice for transport during $6 \mathrm{~h}$. In the laboratory, the containers were place in a refrigerator and the samples were analyzed within $24 \mathrm{~h}$. Thirty samples of apples were collected randomly to represent the real state of the fruits. During the analysis, pieces of different apples were mixed to maintain the randomness of the tests.

Samples from different part of the process were tested in order to provide comprehensive data on the occurrence of molds and yeasts, heat resistant molds (HRM) and Alicyclobacillus at different stages of processing. Two visits were made in the processing plant and the aforementioned samples was taken in each one. Figure 1 presents the flow diagram of the production process indicating the sample localizations.

\section{Molds and Yeast enumeration}

Molds and yeasts were detected by diluting $25 \mathrm{~g}$ of apples and bagasse samples in $225 \mathrm{~mL}$ of $0.1 \%$ peptonate water, followed by a two minute homogenization in a stomacher (ITR, Model 1204). Juice and liquid samples were just diluted in water $(10 \mathrm{~mL}$ of the sample in $90 \mathrm{~mL}$ of the diluent). Subsequently, serial dilutions were made using $0.1 \%$ peptonate water and then samples were plated in duplicate, using Potato Dextrose Agar (PDA, Biolife ${ }^{\circ}, \mathrm{Mi}-$ lan, Italy) acidified to $\mathrm{pH} 3.5$ with $10 \%$ tartaric acid solution. All plates were then incubated at $25{ }^{\circ} \mathrm{C}$ and colonies were counted after 3-5 days. The results were expressed as CFU/mL or CFU/g, depending on the kind of sample (Silva et al., 1997).

\section{Heat resistant molds enumeration}

Apples (previously mixed in a sterile blender) and samples of bagasse were placed each one in a sterile plastic bag and homogenized (100 $\mathrm{g}$ of the samples plus $100 \mathrm{~mL}$ of sterile distillated water) in a stomacher (Pro-analise ${ }^{\circledR}$, Model Boit-Sto1) for $4 \mathrm{~min}$. Two $50 \mathrm{~mL}$ portions of homogenized samples were then transferred to sterile test tubes and heat shocked in a water bath (Tecnal ${ }^{\circledR}$, Model $184 \pm 0.1{ }^{\circ} \mathrm{C}$ ) at $80^{\circ} \mathrm{C}$ for $30 \mathrm{~min}$. Concurrently, $50 \mathrm{~mL}$ samples of concentrated apple juice $\left(70^{\circ}\right.$ Brix $)$ were diluted with $50 \mathrm{~mL}$ of sterile distillated water and then also heated shocked. Liquids samples $\left(35^{\circ}\right.$ Brix or less) were analyzed without any previous dilution and two $50 \mathrm{~mL}$ aliquots of each sample were subjected to the same heat treatment previously described. Samples Brix was measure in a refratometer (AR200 Reichert, USA). After heating, duplicate samples of $50 \mathrm{~mL}$ were cooled and each one was combined with $100 \mathrm{~mL}$ of acidified (pH 3.5) PDA (double agar concentration) supplemented with $50 \mathrm{mg} / \mathrm{L}$ of rose bengal and $4 \mathrm{mg} / \mathrm{L}$ of cloranfenicol. Subsequently, samples were distributed in eight Petri plates which were placed in plastic bags and sealed to prevent drying. The incubation was performed at $30^{\circ} \mathrm{C}$ for up to 30 days. Most viable ascospores germinated and formed visible colonies within 7 to 10 days (Beuchat and Pitt, 2001). The results were expressed as $\mathrm{cfu} / \mathrm{mL}$ or $\mathrm{cfu} / \mathrm{g}$, depending on the kind of sample.

\section{Mold identification}

The mold identification was made by macroscopic and microscopic observations using identification keys as described by Pitt and Hocking (Pitt and Hocking, 1999). Each strain isolated on PDA was transferred to MEA (Malt Extract Agar) and CYA (Czapek Yeast Extract Agar) and G25N (25\% Glycerol Nitrate Agar) media in duplicate trials. Cultures were grown on these three standard media at $25^{\circ} \mathrm{C}$ for 7 days. Those inoculated on CYA was additionally incubated at $5{ }^{\circ} \mathrm{C}$ and $37^{\circ} \mathrm{C}$ for the same period. Furthermore, Czapek agar with $20 \%$ sucrose (CY20S) was prepared to help in the identification of genera suspected to be xerophilic. After incubation, the diameters of macro- 


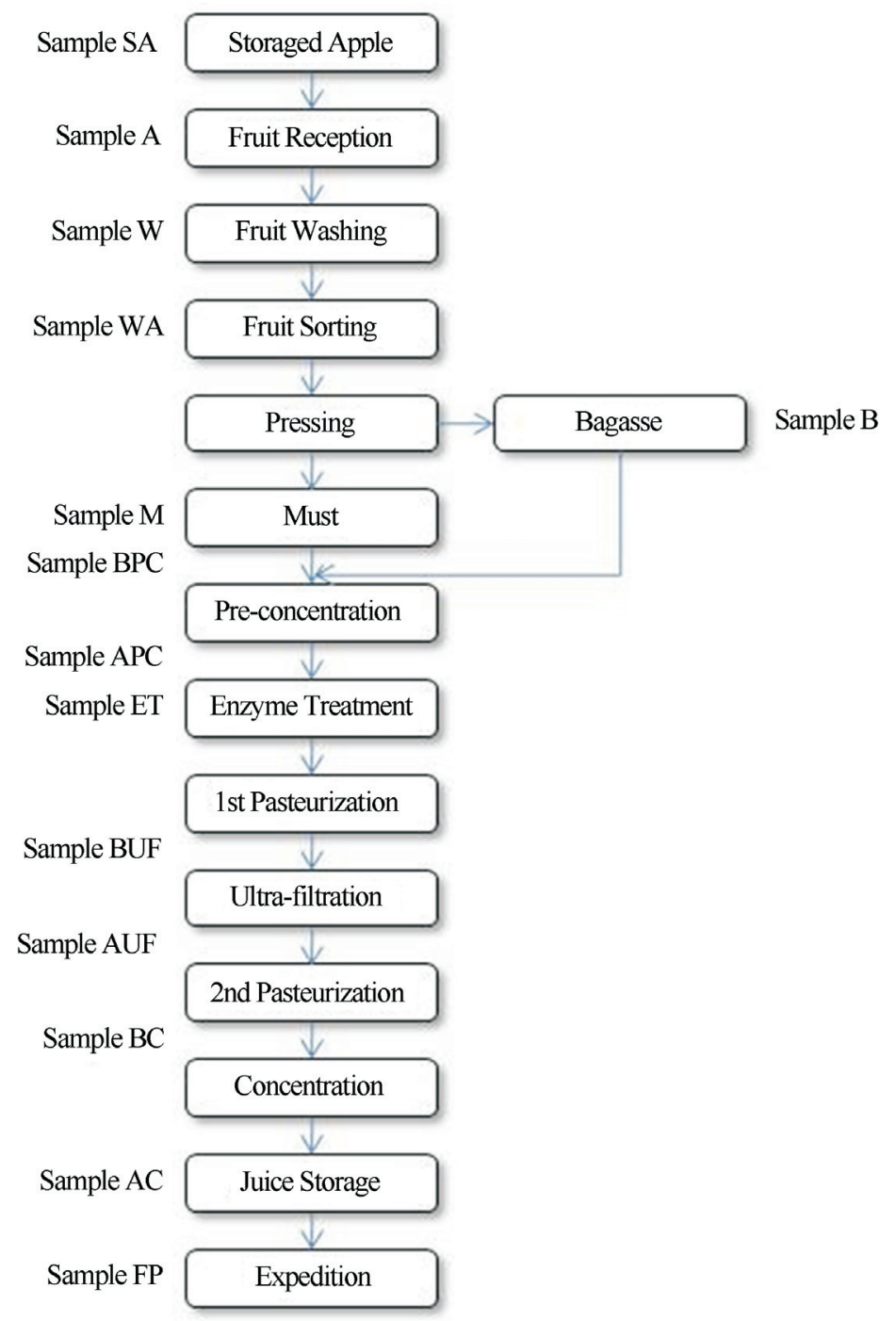

Figure 1 - Concentrated apple juice flow diagram and sampling localizations.

scopic colonies from the underside were measured and macroscopic characteristics such as color, texture and exudates, were analyzed for each colony. Microscopic structures were investigated with a microscopic (Bioval $\left.{ }^{\circledR}\right)$ by using $0.1 \%$ lactofuchsin stain or lactophenol fungal stain (Cotton blue). Yeasts were not identified in this study; only molds were identified (heat resistant or not).

In addition, this investigation identified the mold present in a storage apple (SA) with visual signs of blue mold invasion. For this, a colony of mold from an apple were scraped and transferred to PDA and incubated for 5 days at $25{ }^{\circ} \mathrm{C}$. After the isolation, the strain was sent to André Tosello Foundation (Campinas, SP, Brazil) for further identification and to be deposited at the Collection of Tropical Cultures (CCT).

\section{Alicyclobacillus isolation and enumeration}

The isolation and enumeration of Alicyclobacillus spp. (ATSB) was realized according to Eguchi et al. 1999.
In order to count ATSB, samples of concentrate juice were diluted prior to analysis $(10 \mathrm{~mL}$ of juice in $90 \mathrm{~mL}$ of sterile distilled water). The other liquid samples $(10 \mathrm{~mL})$ were diluted in $90 \mathrm{~mL}$ of BAT (Bacillus alicycloterrestris) broth. Samples of apples and bagasse ( $25 \mathrm{~g}$ ) were blended with $225 \mathrm{~mL}$ of BAT broth in a stomacher for $2 \mathrm{~min}$. The diluted samples were heated shocked at $80{ }^{\circ} \mathrm{C}$ for $10 \mathrm{~min}$, cooled at $40-45^{\circ} \mathrm{C}$ and their aliquots were plated on BAT agar by the pour plate technique. All plates were incubated at $50{ }^{\circ} \mathrm{C}$ for 4 days (plates were monitored for up to 10 days). After incubation time, the colonies were enumerated and the results were expressed in $\mathrm{cfu} / \mathrm{g}$ or $\mathrm{cfu} / \mathrm{mL}$.

Concurrently, a technique for detecting was also performed with the same samples. In the detection method, the samples were prepared as described above and heated shocked at $80{ }^{\circ} \mathrm{C}$ for $10 \mathrm{~min}$. Subesequently, the samples were incubated at $50{ }^{\circ} \mathrm{C}$ for $24 \mathrm{~h}$ to enrich the cultures. An aliquot of $1 \mathrm{~mL}$ of the enrichment culture was directly pour plated with BAT agar and incubated at $50{ }^{\circ} \mathrm{C}$ for 4 days 
(plates were monitored for up to 10 days). This result was express as the absence or presence of Alicyclobacillus (ATSB).

\section{Alicyclobacillus morphological characterization and identification}

Single colonies present at the surface of BAT agar were picked off and streaked onto the same medium used for isolation. Plates were incubated at $50{ }^{\circ} \mathrm{C}$ for 48 to $72 \mathrm{~h}$ and then, the overall microscopic morphology and the presence or characteristics of spores were investigated. Strains with characteristic morphology were inoculated onto Nutrient agar (Biolife ${ }^{\circledR}$, Milan, Italy) at $\mathrm{pH} 7$ and incubated at $50{ }^{\circ} \mathrm{C}$ to confirm the acidophilic nature of the isolates and discard the presence of acid tolerant bacilli.

The isolated Alicyclobacillus strains were sent to André Tosello Foundation (Campinas, Brazil) for further identification on basis of standard biochemical and morphological tests and also based on 16S rRNA sequence similarity. Also, the isolated strains were deposited at the Collection of Tropical Cultures (CCT).

\section{Results}

\section{Molds and Yeast}

The counts of molds and yeast in this study are shown in Table 1. In order to express the results, each strain was encoded according to the initial letters of the sample which was isolated and preceded by a number that represents the sequence of isolation.

A total of 13 strains of molds were isolated of which 12 were identified as belonging to the genus Penicillium: 1 strain from sample SA (1SA), 1 strain from sample A (1A),

Table 1 - Mean values of molds and yeast in different stages of a concentrated apple juice process line.

\begin{tabular}{ll}
\hline Sample (code) & $\begin{array}{l}\text { Mean values of molds and yeast } \\
\text { molds and yeast }\end{array}$ \\
\hline Apples at the reception (A) & $1.3 \times 10^{5} \mathrm{cfu} / \mathrm{g} \pm 0.57$ \\
Wash water (W) & $6.6 \times 10^{5} \mathrm{cfu} / \mathrm{mL} \pm 0.71$ \\
Washed apples (WA) & $1.3 \times 10^{7} \mathrm{cfu} / \mathrm{g} \pm 0.63$ \\
Bagasse (B) & $4.5 \times 10^{5} \mathrm{cfu} / \mathrm{g} \pm 0.57$ \\
Must (M) & $9.3 \times 10^{4} \mathrm{cfu} / \mathrm{mL} \pm 1.16$ \\
Before pre-concentration (BPC) & $7.0 \times 10^{5} \mathrm{cfu} / \mathrm{mL} \pm 0.37$ \\
After pre-concentration (APC) & $<10 \mathrm{cfu} / \mathrm{mL} \pm 0.00$ \\
Enzymatic treatment (ET); & $1.5 \times 10^{2} \mathrm{cfu} / \mathrm{mL} \pm 0.64$ \\
Before ultra-filtration (BUF) & $3.0 \times 10^{2} \mathrm{cfu} / \mathrm{mL} \pm 0.80$ \\
After ultra-filtration (AUF) & $2 \mathrm{cfu} / \mathrm{mL} \pm 0.55$ \\
Before concentration (BC) & $5 \mathrm{cfu} / \mathrm{mL} \pm 0.67$ \\
Concentrate apple juice (AC) & $1.7 \times 10^{2} \mathrm{cfu} / \mathrm{mL} \pm 0.87$ \\
Final product (FP) & $<10 \mathrm{cfu} / \mathrm{mL} \pm 0.00$ \\
\hline
\end{tabular}

2 strains from sample $\mathrm{W}(1 \mathrm{~W} ; 2 \mathrm{~W}), 2$ strains from sample WA (1WA; 2WA), 3 strains from sample B (1B; 2B; 3B), 1 strain from sample $\mathrm{M}(1 \mathrm{M})$ and 2 strains from sample $\mathrm{BPC}$ (1BPC; 2BPC). From this total, the species was encoded as 1SA, 1A, 1W, 1WA, 1B and 2BPC was identified as Penicillium expansum. The strain 1SA was deposited in the Tropical Collection Cultures and re-encoded as Penicillium expansum CCT 7549. The strain isolated from sample AC was identified as Talaromyces sp. (1AC). Only yeasts (not identified in this study) were verified in the samples from ET, BUF, AUF and BC.

The macroscopic and microscopic description of molds isolated in this study is shown below. Furthermore, some pictures of their structures are exhibited in Figure 2.

The isolates identified as Penicillium sp. (2W, 2WA, 2B, 3B, 1M and 1BPC) showed macroscopically colonies with different characteristics of color, texture and size, depending on the strain. It was observed that all strains grow on CYA, MEA and $\mathrm{G} 25 \mathrm{~N}$ at $25^{\circ} \mathrm{C}$ but not on CYA at $37^{\circ} \mathrm{C}$ and $5^{\circ} \mathrm{C}$. Microscopic observation revealed the presence of different types of penicilli and spherical or ellipsoidal conidia.

The isolates $1 \mathrm{SA}, 1 \mathrm{~A}, 1 \mathrm{~W}, 1 \mathrm{WA}, 1 \mathrm{~B}$ and $2 \mathrm{BPC}$ were identified as $P$. expansum. Their colonies on CYA (25$35 \mathrm{~mm}$ diameter) were colonies centrally colored from dull green to slightly brown, surrounded (annularly) by a thick external layer of white color, clear to pale yellow exudates, tufted surface velutinous to floccose, moderate sporulation and a deep brown underside (caramel). The colors of colonies on MEA (20-35 mm diameter) ranged as seen on CYA to slightly greyer with orange exudates and a pale underside. Colonies on G25N (15-20 mm diameter) were centrally cream colored, surrounded by a thin white external layer with a dull brown underside. No growth was observed at $5{ }^{\circ} \mathrm{C}$ and $37{ }^{\circ} \mathrm{C}$. Microscopically, conidiophores with smooth walls bearing terminal penicilli terverticullate (The strain 1SA, encoded as $P$. expansum CCT 7549, is represented in the Figure 2a) and smooth walled ellipsoidal conidia (4 to $5 \mu \mathrm{m}$ long) were observed. In addition, $14.5-19.0 \mu \mathrm{m}$ long metula and 10.0-14.0 $\mu \mathrm{m}$ long phialides were observed.

The strain codified as $1 \mathrm{AC}$ showed colonies on CYA of 60-70 mm of diameter, a floccose appearance, uniformly pale olive brown color and a pale underside. Colonies on MEA (covering the whole Petri dish) were very similar to those in CYA. Colonies on G25N (15-17 mm of diameter) were similar to those on CYA. At $37^{\circ} \mathrm{C}$ on CYA, colonies covering the whole Petri dish were similar to those at $25^{\circ} \mathrm{C}$. No germination was observed at $5{ }^{\circ} \mathrm{C}$. Microscopically (Fig. $2 \mathrm{k}, 1, \mathrm{~m}, \mathrm{n}$ ) the strain developed the characteristic of a HRM showing yellow gymnothecia with closely interwoven hyphae and ascus characteristic of the teleomorph Talaromyces. The conidia (around $5 \mu \mathrm{m}$ long) were strictly cylindrical to pyriform. Talaromyces is associated with an anamorphic state characteristic of Penicillium, 


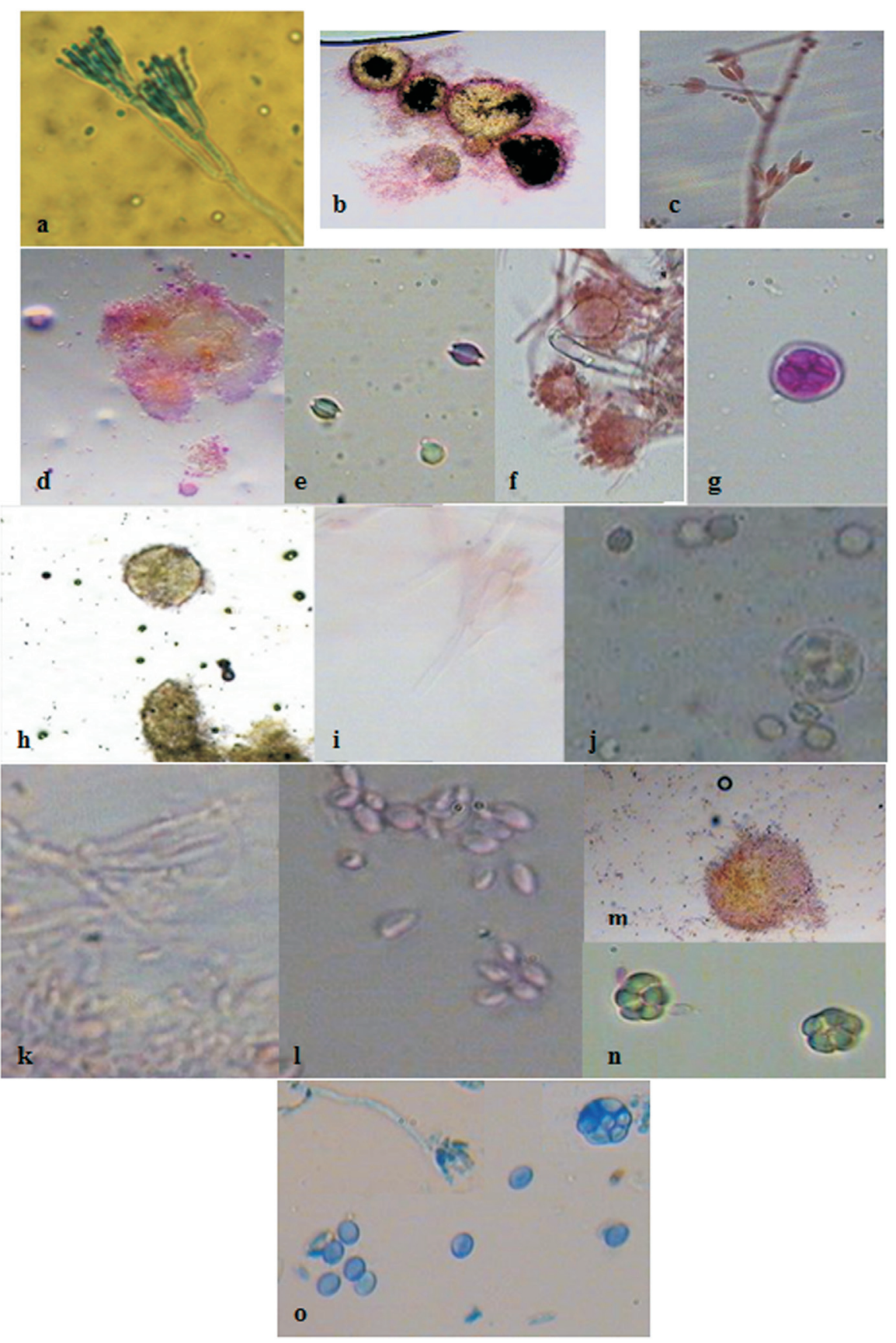

Figure 2 - Microscopic structures: (a) P. expansum CCT7549; (b) Eupenicillium sp. 1BPFr (cleistotecium structure); (c) Eupenicillium cinnamopurpureum $1 \mathrm{Wr}$ (Penicillium anamorph state); Eurotium sp. 1WAr structures: (d) cleistotecia, (e) ascospores, (f) Aspergillus (anamorph state), (g) asci; Neosartorya fischeri 2WAr structures: (h) cleistotecia, (i) Aspergillus (anamorph state), (j) asci and ascospores; Talaromyces sp. 1AC structures: (k) Paecilomyces (anamorph state), (1) conidia, (m) gymnotheciium, (n) ascus; (o) B. fulva 1FP structures (asci, ascospores and Paecilomyces (anamorph state). All microscopic observations were made in $400 \mathrm{X}$, except to for pictures of cleistotecium and gymnotecia (b; $\mathrm{d} ; \mathrm{h}$ and $\mathrm{m}$ ) which were made $40 \mathrm{X}$.

Paecilomyces or Geosmithia. The observation of the anamorph showed phialides alone characteristically swollen at the base and gradually narrowing into a long beak. Based on this, considering the characteristic of the conidiophores borne and conidia shape, the anamorph state was identified as Paecilomyces.

On CYA at $25{ }^{\circ} \mathrm{C}$, the strain of Neosartorya fischeri (2WAr) showed colonies (around $70 \mathrm{~mm}$ of diameter) col- ored white to pale yellow (centrally) with plane and sparse surface with a floccose texture and pale underside. Similarly on MEA, colonies ( $75 \mathrm{~mm}$ of diameter) were white to pale cream showing a plane surface with a floccose texture and pale underside. Colonies on $\mathrm{G} 25 \mathrm{~N}$ (15 mm diameter) were colored white with a pale underside. At $37{ }^{\circ} \mathrm{C}$ on CYA, colonies covering the whole Petri dish were white to pale cream, sulcate, floccose and a pale underside. No 
growth was observed at $5{ }^{\circ} \mathrm{C}$. Microscopic observations showed (Fig. 2 h, i, j) clear cleistothecia, ascus and ornamented ascospores $(7.5 \mu \mathrm{m}$ long) with two longitudinal flanges. The anamporph Aspergillus with the head formed from phialides was alone observed.

Eupenicillium cinnamopurpureum (1Wr) presented colonies on CYA (10-20 mm of diameter) of dense texture, sulcate, clear exudate of white color and pale cinnamon underside. Colonies on MEA (12-17 mm of diameter) were colored white with a pale underside. Colonies on G25N (12-15 mm of diameter) were colored white with a cinnamon-colored central region and a pale cinnamon underside. At $37{ }^{\circ} \mathrm{C}$ on $\mathrm{CYA}$, colonies with a diameter of 5-7 mm were colored white. No growth was observed at $5{ }^{\circ} \mathrm{C}$. Microscopic observations showed a strictly monoverticulate penicillin with ampulliform phialides (Figure $2 \mathrm{c}$ ) and ellipsoidal spores. It was not possible to observe cleistothecia, however, Pitt and Hocking (Pitt and Hocking, 1999) affirmed that some isolates fail to produce cleistothecia at all.

Colonies of Eupenicillium sp. (1BPCr) on CYA (45-50 $\mathrm{mm}$ of diameter), were colored white, radially sulcate, with a dense texture and pale yellow underside. Colonies on MEA (50-55 mm of diameter) were similar to CYA. On G25N (5-7 mm of diameter) colonies were colored white with a floccose texture and pale yellow underside. At $37^{\circ} \mathrm{C}$, white colonies with a diameter of 25-30 mm were radially sulcate with a pale yellow underside. No germination was observed at $5{ }^{\circ} \mathrm{C}$. Microscopic observations showed yellow cleistothecia (Figure 2b), however it was difficult to observe ascospores.

The colonies of Eurotium sp. (1WAr) on CYA (17-20 mm of diameter) were dense, sulcate with an intense yellow color and an orange underside. Both the colonies and the underside on MEA (5-10 mm of diameter) were orange. Colonies on G25N (30-35 mm of diameter) were pale yellow in color with a yellow underside. Colonies on CY20S (30-35 mm) were sulcate, with white mycelium at the margins, becoming yellow with an intense orange center and an orange underside. No growth was observed at $5{ }^{\circ} \mathrm{C}$. Microscopically (Figure $2 \mathrm{~d}, \mathrm{e}, \mathrm{f} \mathrm{g}$ ), ascospores were not evident within 7 days, however after 14 days of incubation, ascospores (around $5 \mu \mathrm{m}$ long) showing smooth walls with two prominent, parallel longitudinal flanges were observed. Furthermore, yellow cleistothecia, ascus and the anamorph Aspergillus producing only phialides was found.

Eurotium sp. (3WAr) showed colonies on CYA (20-22 mm of diameter), sulcate with yellow at the margins, becoming orange brown in the central area with a very intense orange underside. Colonies on MEA (27-30 mm of diameter) were sulcate, showing an intense orange color and the same color on the underside side. No growth was observed at $5^{\circ} \mathrm{C}$ or $37^{\circ} \mathrm{C}$. Colonies on CY20S showed a diameter of $20 \mathrm{~mm}$ after 7 days of incubation reaching $40 \mathrm{~mm}$ after 14 days. These colonies showed a texture plane, sul- cate with a clear color at the margins becoming intensely orange at the center with the same color on the underside. Microscopic observations showed (after 14 days of incubation) ellipsoidal ascospores without double flanges. The anamorph Aspergillus with the head formed from phialides alone and also cleistothecium enveloped in yellow hyphae was observed.

Byssochlamys fulva (1FP) showed colonies on CYA and MEA covering the whole Petri dish with sparse, low floccose, heavy conidial production and were colored olive brown on MEA and on CYA with white filaments on CYA. The underside color was pale brown. Colonies on $\mathrm{G} 25 \mathrm{~N}$ (5-8 mm of diameter) were olive brown. No growth was observed at $5{ }^{\circ} \mathrm{C}$. Microscopically (Figure $2 \mathrm{f}$ ), there were not any kind of bodies typically present in most of ascomycetes. Furthermore, ellipsoidal ascospores ( $5 \mu \mathrm{m}$ long) with smooth walls and also asci $(10 \mu \mathrm{m})$ were observed. Anamorphic reproductive structures of penicillin were observed.

\section{Alicyclobacillus sp.}

The incidence of Alicyclobacillus was only verified in those samples that were subjected to the detection method, so that the result was expressed based only on the presence or absence of Alicyclobacillus (ATSB). The strains ET and BUF were identified as Alicyclobacillus acidoterrestris.

\section{Discussions}

The survey of mold and yeasts from a concentrated apple juice process showed a high contamination mainly on the steps before heat treatment (Table 1). After pre-concentration stage $\left(110-115{ }^{\circ} \mathrm{C}\right.$ for $\left.30 \mathrm{~s}\right)$ the number of molds and yeast decreases from $>10^{7} \mathrm{cfu} / \mathrm{mL}$ to $<10 \mathrm{cfu} / \mathrm{mL}$. However, enzyme treatment stage increased their number to $>10^{2} \mathrm{cfu} / \mathrm{mL}$ and even after pasteurization stages the number of molds and yeast was kept. However, in the end of the process, the final product decreased their count to $<10 \mathrm{cfu} / \mathrm{mL}$, indicating that raw apple juice is not homogeneous concerning its mold and yeast contamination and the various stages of manufacture are really necessary in order to obtain a concentrate apple with no contaminarion.

The mold Penicillium was the prevalent genera found. However, the pre-concentration step was enough to completely destroy Penicillium spores since they were not found in the following stages. Labuda et al. (2005) investigated the incidence of toxinogenic fungi in fruits and also reported Penicillium as the major contaminant. Other researchers observed that $P$. expansum (30-62\%) was the most prevalent species on apples in storage rooms (Amiri and Bompeix, 2005). In this present study, half of the Penicillium strains were identified as $P$. expansum representing a concern for apple juice processing since it is the typical contaminant of apple brown rot having the ability to grow at low temperatures and to produce patulin on de- 
cayed fruits (Amparo et al., 2012; Doores, 1983; Jackson et al., 2003; Salomão et al., 2009a). During the off-season, juice companies are supplied with apples stored in packing houses. Therefore, the presence of $P$. expansum in apples should be considered a possible consequence of postharvest handling of fruits associated with the extension and conditions of storage. During the present investigation, as cited by other authors (Sydenham et al., 1995), it was observed that at several times the apples are not processed as soon as received in the processing plant. This situation leads to deck storage (under no refrigerated conditions) for sometimes more than 5 days, resulting in serious implications in the level of patulin (Sydenham et al., 1997). Therefore, monitoring the quality of apple lots under a rigid selection criterion during the reception step and minimizing storage at room temperature should be considered important measures to control this toxigenic mold (Fao, 2003).

The sample of wash water also showed a high contamination by molds and yeast $\left(>10^{5} \mathrm{cfu} / \mathrm{mL}\right)$, including $P$. expansum (Codex, 2003). In the wash step, the high-pressure water sprayed against apples helps in the removal of rotten parts which contain high levels of toxin (Acar et al., 1998). However, spores will be suspended in the water causing a possible cross contamination and also increasing the risk of mold growth during bulk storage (Fao, 2003). The increase of the counts of molds and yeast observed in the washed apples $\left(>10^{7} \mathrm{cfu} / \mathrm{mL}\right)$, including $P$. expansum, proof that cross contamination is real and possible. Therefore is important to use a sanitizer, such as chlorine, during this step in order to reduce $P$. expansum spores (Salomão et al., 2008a, 2009b). Besides, the apple sorting should be rigorous enough to remove, as far as possible, rotten fruits, even those with only small areas of rot (Codex, 2003).

Talaromyces sp. (1AC) was the mold isolated from the concentrated juice. This mold is a HRM that has been isolated on several occasions in screening fruit juices (Pitt and Hocking, 1999). The sequence of heat shocks applied during the process probably caused the activation of its spores from the asexual to a sexual state. The presence of Talaromyces species in the concentrated apple juice implies a concern because they cause spoilage in heat-treated products and members of this genus are known to produce the mycotoxin talaromycin (Enigl et al., 1993). Their ascospores are extremely heat resistant and can survive 5 to 12 min of heating at $100{ }^{\circ} \mathrm{C}$ (Tournas, 1994; Pitt and Hocking, 1999).

The genus Eupenicillium was isolated from wash water $(1 \mathrm{Wr})$ and before concentration treatment (1BPCr). Another study also found this HRM from a concentrated apple juice process in a step after pasteurization (Salomão et al., 2008b).

N. fischeri was detected in washed apples. N. fischeri can be introduced in the process through contaminated apples and its spores can be suspended in the water causing a possible cross contamination. Other study also related the presence of this same HRM species in apple products (Salomão et al., 2008b). N. fischeri ascospores showed high resistance in juices and survived to a heat treatment of $94{ }^{\circ} \mathrm{C}$ for $20 \mathrm{~min}$ in apple juice (Salomão et al., 2004, 2007, $2008 \mathrm{~b}$ ). Some strains of $N$. fischeri are capable of producing toxins such as fumitremorgins and verruculogen (Tournas, 1994).

Eurotium species also were detected among the HRM and their presence in the apples was unusual. However their presence was detected in washed apples and wash water. Some species of Eurotium are a risk to the thermal process since they also produces ascopores which would include them to the list of resistant fungi (Splittsoesser et al., 1989; Yildiz and Coksöyler, 2002). Their xerophilic characteristic is probably the major reason for their stability during dormancy (Eicher and Ludwig, 2002). The heat resistance of Eurotium haerbariorum, isolated from a spoilage outbreak involving grape preserves, showed $\mathrm{D}_{70}{ }^{\circ} \mathrm{C}$ of $2.5 \mathrm{~min}$ in $5^{\circ}$ Brix grape juice and $\mathrm{D}_{71}{ }^{\circ} \mathrm{C}$ of $5.2 \mathrm{~min}$ in $65^{\circ}$ Brix juice (Splittstoesser et al., 1989).

The presence of B. fulva in the concentrated juice demonstrated the ability of its ascospores to remain viable after being submitted to the high temperatures applied during processing. A study demonstrated that even at a very low initial contamination, clarified apple juice can be easily spoiled by B. fulva (Sant'Ana et al., 2010a). A strain of $B$. fulva IOC 4518, isolated from apples, survived heating at $95^{\circ} \mathrm{C}$ for $20 \mathrm{~min}$ (Salomão et al., 2008b) and its D values in apple juice at $85^{\circ} \mathrm{C}, 90{ }^{\circ} \mathrm{C}, 92{ }^{\circ} \mathrm{C}$ and $95^{\circ} \mathrm{C}$ were 64.5 , 16.6, 6.3 and $3.1 \mathrm{~min}$, respectively (Sant'Ana et al., 2009). A study showed that from 16 samples of concentrate apple juice analyzed, $25 \%$ belonged to the Byssochlamys genera. Three strains were identified as $B$. fulva and one strain as $B$. nivea (Welke et al., 2009). In addition to patulin, other metabolites have been reported to be produced by B. fulva such as byssochlamic acid and byssotoxin A (Tournas, 1994; Sant'Ana et al., 2010b).

Although the incidence of HRM in the concentrate apple juice was low (Table 2), all heat resistant genus cited in the literature were detected in this investigation. Based on this, control measures should be studied in order to minimize the contamination by these microorganisms.

The presence of $A$. acidoterrestris in the samples is in agreement with other studies that report its incidence in a wide range of fruit juices as well as processing facilities. The contamination of fruit surfaces probably is from soil during production and harvesting (Chen et al., 2006; Grande et al., 2005; Murakami et al., 1998). Therefore, considering that Alicyclobacillus are soil-borne, its control should start in the fields along with proper cleaning of fruits at the beginning of processing (Groenewald et al., 2009). Groenewald et al. also reported the isolation of $A$. acidoterrestris from wash water and flume water, which increases the risk of possible recontamination by this bacterium through the water. 
Table 2 - Mean values of heat resistant molds (HRM) and the identified species in different stages of a concentrated apple juice process line.

\begin{tabular}{lcc}
\hline Sample (code) & Mean values of HRM & Identified species of HRM (code) \\
\hline Wash water (W) & $1 \mathrm{cfu} / 100 \mathrm{~mL} \pm 0.00$ & Eupenicillium cinnamopurpureum (1Wr) \\
Washed apples (WA) & $3 \mathrm{cfu} / 100 \mathrm{~g} \pm 1.41$ & Eurotium sp. (1WAr) Neosartorya fischeri (2WAr) Eurotium sp. (3WAr) \\
Before pre-concentration (BPC) & $1 \mathrm{cfu} / 100 \mathrm{~mL} \pm 0.70$ & Eupenicillium sp. (1BPCr) \\
Final product (FP) & $2 \mathrm{cfu} / 100 \mathrm{~mL} \pm 1.41$ & Byssochlamys fulva (1FPr) \\
\hline
\end{tabular}

In this present survey, $A$. acidoterrestris was detected in the step of enzymatic treatment and step before ultra filtration. These facts showed the high resistance of its spores in remaining viable even after submitted to the heat treatments applied in the pre-concentration stage $\left(110-115{ }^{\circ} \mathrm{C}\right.$ for $30 \mathrm{~s})$ and in the first pasteurization stage $\left(85-90{ }^{\circ} \mathrm{C}\right.$ for $30 \mathrm{~s})$. The $\mathrm{D}$ values for $A$. acidoterrestris in apple juice at 85,90 and $95{ }^{\circ} \mathrm{C}$ were 56,23 and 2.8 min, respectively (Splittstoesser et al., 1994). Since A. acidoterrestris is a thermoacidophilic and spore-forming bacterium they can survive in acid media (such as apple juice) and grow at temperatures higher than $20^{\circ} \mathrm{C}$, thereby having the potential to spoil the shelf stable products during storage (Chen et al., 2006; Chmal-Fudali and Papiewska, 2011). Although $A$. acidoterrestris is not pathogenic, it is recognized as a problem in the juice industries worldwide since spore-related juice spoilage may result in bad smelling compounds (Jensen and Whitfield, 2002; Splittsoesser et al., 1998; Walls and Chuyate, 2000).

The presence of $P$. expansum in the raw material represents a likely risk of patulin in the final product, since this toxin shows relatively high heat stability in an acidic environment. The detection of $B$. fulva and A. acidoterrestris CCT 7548 in the stages after heat treatment demonstrated their high heat resistance and also the possibility of toxins and off-flavors remaining in the apple juice. Besides, it was demonstrated that Byssochlamys spp. are able to produce patulin in apple juice packages during storage and distribution (Sant'Ana et al., 2010b). Therefore, this research concluded that $P$. expansum, B. fulva and $A$. acidoterrestris are important biologic hazards for apple juice products. Furthermore, the application of more severe thermal treatments to inactivate resistant spores and toxins is impracticable for fruit juices. So, surveys should find new strategies to reduce the target microorganisms in raw material, controlling the initial contamination of fruits.

\section{Acknowledgments}

The authors gratefully acknowledge the Capes Foundation (Brazil) and CNPQ (National Counsel of Technological and Scientific Development, Brazil) for Beatriz C. M. Salomão and Chalana Müller scholarships, respectively. Besides, we would like to thank David C. Manns from Cornell University for English editing.

\section{References}

Acar J, Gökmen V, Taydas EE (1998) The effects of processing technology on the patulin content of juice during commercial apple juice concentrate production. Z. Lebensm Unters Forsch A 207:328-331.

Amiri A, Bompeix G (2005) Diversity and population dynamics of Penicillium spp. on apples in pre- and postharvest environments: consequences for decay development. Plan Pathol 54:74-81.

Amparo HC, Cavichon E, Baratto CM, Tondo EC, Gelinski JMLN (2012) Determination of patulin in apple juice from Fuji apples stored in different conditions in southern Brazil. J Food Res 1:54-57.

Bahçeci KS, Acar J (2007) Modeling the combined effects of pH, temperature and ascorbic acid concentration on the heat resistance of Alicyclobacillus acidoterrestris. International J Food Microbiol 120:266-273.

Beuchat LR, Pitt JI (2001) Detection and enumeration of heat-resistant molds. In Downes, F.P.; Ito, K. (eds.). Compendium of the methods for the microbiological examination of foods (4th ed.). APHA, Washington, D.C, p. 217-222.

Chang SS, Kang DH (2004) Review: Alicyclobacillus sp. in the fruit juice industry: history, characteristics, and current isolation/detection procedures. Crit Rev Microbiol 30:55-74.

Chen S, Tang Q, Zhang X, Zhao G, Hu X, Liaod X, Chend F, Wud J, Xiang H (2006) Isolation and characterization of thermoacidophilic endospore-forming bacteria from the concentrated apple juice-processing environment. Food Microbiol 23:439-445.

Chmal-Fudali E, Papiewska A (2011) The possibility of thermal inactivation of Alicyclobacillus acidoterrestris spores in fruit and vegetable juices. Biotechnol Food Sci 75:87-96.

Codex, Codex Alimentarius Commission (2003) Code of practice for the prevention and reduction of patulin contamination in apple juice and apple juice ingredients in other beverages. CAC/RCP 50:1-6.

Doores S (1983) The microbiology of apples and apple products. Crit Rev Food Sci Nutr 19:133-149.

Eguchi SL, Manfio G, Pinhatti ME, Azuma E, Variane SF (1999) Acidothermophilic sporeforming bacteria (ATSB) in orange juice: Detection Methods, Ecology, and Involvement in the deterioration of fruit juices. Coleção de culturas Trocal (CCT) - Fundação André Tosello \& ABECitrus, Campinas. Available at: http://www.abecitrus.com.br. Accessed 18 June 2010.

Eicher R, Ludwig H (2002) Influence of activation and germination on high pressure inactivation of ascospores of the mould Eurotium repens. Comp. Biochem. Physiol Part A 131:595604. 
Enigl DC, King Jr AD, Török T (1993) Talaromyces trachyspermus, a heat-resistant mold isolated from fruit juice. J Food Prot 56:1039-1042.

Fao - Food and Agriculture Organization of the United Nations. (2003). Manual on the application of the HACCP system in mycotoxin prevention and control. Fao Food Nutr Paper 73:121-124.

Grande MJ, Lucas R, Abriouel H, Ben Omar N, Maqueda M, MartiNez-Bueno M, Martínez-Cañamero M, Valdivia E, Gálvez A (2005) Control of Alicyclobacillus acidoterrestris in fruit juices by enterocin AS-48. Int J Food Microbiol 104:289297.

Groenewald WH, Gouws PA, Witthuhn RC (2009) Isolation, identification and typification of Alicyclobacillus acidoterrestris and Alicyclobacillus acidocaldarius strains from orchard soil and the fruit processing environment in South Africa. Food Microbiol 26:71-76.

Jackson LS, Beacham-Bowden T, Keller SE, Adhikari C, Taylor KT, Chirtel SJ, Merker RI (2003) Apple quality, storage, and washing treatments affect patulin levels in apple cider. J. Food Prot 66:618-624.

Jensen N, Whitfield FB (2002) Role of Alicyclobacilllus acidoterrestris in the development of a disinfectant taint shelf-stable fruit juice. Lett Appl Microbiol 36:9-14.

Kupferman E (1986) Control of Major Postharvest Apple Diseases. Post Harvest Pomology Newsletter 4. Available at: http://postharvest.tfrec.wsu.edu/pgDisplay.php?article=N4I3B. Accessed 8 January 2010.

Labuda R, Krivánek L, Tancionová D, Mátéová S, Hrubcová S (2005) Mycological survey of ripped service tree fruits (Sorbus domestia L.) with an emphasis on toxinogenic fungi. Int J Food Microbiol 99:215-223.

Liu B, Yu F, Wu T, Li S, Su M, Wang M, Shih S (2003) Evaluation of genotoxic risk and oxidative DNA damage in mammalian cells exposed mycotoxin, patulin and citrinin. Toxicol Appl Pharmacol 191:255-263.

McKnight IC, Eiroa MNU, Sant'Ana AS, Massaguer PR (2010) Alicyclobacillus acidoterrestris in pasteurized exotic Brazilian fruit juices: Isolation, genotypic characterization and heat resistance. Food Microbiol 27:1016-1022.

Murakami M, Tedzuka H, Yamazaki K (1998) Thermal resistance of Alicyclobacillus acidoterrestris spores in different buffers and $\mathrm{pH}$. Food Microbiol 15:577-582.

Peña WEL, Faria JAF, Massaguer PR (2004) Development of a predictive model on the growth of the spoilage mould, Paecilomyces variotti, in pineapple juice. Fruit Process 6:420-426.

Piecková E, Samson RA (2000) Heat resistance of Paecilomyces variotii in sauce and juice. J Indust Microbiol Biotechnol 24:227-230.

Pitt JI, Hocking AD (1999) Fungi and Food Spoilage. (2nd ed.). Aspen Publishers, Inc, Gaithersburg, Maryland.

Salomão BCM, Aragão GMF, Churey JJ, Padilla-Zakour OI, Worobo RW (2009) Influence of storage temperature and apple variety on patulin production by Pencillium expansum. J Food Protect 72:81-87.

Salomão BCM, Aragão GMF, Churey JJ, Worobo RW (2008) Efficacy of sanitizing treatments against Penicillium expansum inoculated on six varieties of apples. J Food Protect 71:643-647.
Salomão BCM, Churey JJ, Aragão GMF, Worobo RW (2009) Modeling Penicillium expansum resistance to thermal and chlorine treatments. J Food Protect 72 2618-2622.

Salomão BCM, Massaguer PR, Aragão GMF (2008) Isolamento e seleção de fungos filamentosos termorresistentes do processo produtivo de néctar de maçã. Ciênc Tec Ali 1:116-121.

Salomão BCM, Slongo AP, Aragão GMF (2007) Heat resistance of Neosartorya fischeri in various juices. LWT-F Sci Technol 40:676-689.

Salomão BCM, Costa CA, Massaguer PR, Aragão GMF (2004) Influência de diferentes pHs do meio de aquecimento na resistência térmica de Neosartorya fischeri isolado do processo produtivo de néctar de maçã. Ali Nutr 15:7-10.

Sanderson PG, Spotts RA (1995) Postharvest decay of winter pear and apple fruit caused by species of Penicillium. Phytopathology 85:103-110.

Sant Ana AS, Dantigny P, Tahara AC, Rosenthal A, Massaguer PR (2010) Use of a logistic model to assess spoilage by Byssochlamys fulva in clarified apple juice. Int $\mathrm{J}$ Food Microbiol 137:299-302.

Sant Ana AS, Rosenthal A, Massaguer PR (2009) Heat resistance and the effects of continuous pasteurization on the inactivation of Byssochlamys fulva ascospores in clarified apple juice. J Appl Microbiol 107:197-209.

Sant'Ana AS, Simas RC, Almeida CAA, Cabral EC, Rauber RH, Mallmann CA, Eberlin MN, Rosenthal A, Massaguer PR (2010) Influence of package, type of apple juice and temperature on the production of patulin by Byssochlamys nivea and Byssochlamys fulva. Int J Food Microbiol 142:156-163.

Silva N, Junqueira VCA, Silveira NFA, Taniwaki MH, Santos RFS, Gomes RAR (1997) Manual de métodos de análise microbiológica de alimentos. Varela, São Paulo.

Silva SJN, Schuch PZ, Bernardi CR, Vainstein MH, Jablonski A, Bender RJ (2007) Patulin in food: state-of-the-art and analytical trends. ver Brasil Fruticul 29:406-413.

Splittstoesser C, Lee Y, Churey JJ (1998) Control of Alicyclobacillus in the juice industry. Dairy Food Environ Sanit 18:585-587.

Splittstoesser DF, Churey JJ, Lee CY (1994) Growth characteristics of aciduric sporeforming bacteria isolated from fruit juices. J Food Protect 57:1080-1083.

Splittstoesser DF, Lammers JM, Downing DL, Churey JJ (1989) Heat resistance of Eurotium herbariorum, a xerophilic Mold. J Food Sci 54:683-685.

Spotts RA, Cervantes LA (1993) Filtration to remove spores of Penicillium expansum from water in pome fruit packinghouses. Tree Fruit Postharv J 4:6-8.

Spotts RA, Holmes RJ, Washington WS (1988) Sources of spores and inoculum concentration related to postharvest decay of apple and pear. Aust J Plan Pathol 17:48-52.

Suresh ER, Ethiraj S, Jayaram HL (1996) Heat resistance of Neosartorya fischeri isolated from grapes. J Food Sci Technol 33:76-77.

Sydenham EW, Vismer HF, Marasas WF, Brown NL, Schlecter M, Rheeder JP (1997) The influence of deck storage and initial processing on patulin levels in apple juice. Food Addit Contamin 45:429-434.

Sydenham EW, Vismer HF, Marasas WFO, Brown N, Schlechter M, Van Der Westhuizen L, Rheeder JP (1995) Reduction of patulin in apple juice samples influence of initial processing. Food Control 6:195-200. 
Tournas V (1994) Heat Resistant Fungi of importance to the food and beverage industry. Crit Rev Microbiol 20:243-263.

Ugwuanyi JO, Obeta JAN (1999) Pectinolytic and cellulolytic activities of heat resistant fungi and their macerating effects on mango and African mango. J Sci Food Agric 79:1054-1059.

Walls I, Chuyate R (2000) Spoilage of fruit juice by Alicyclobacillus acidoterrestris. Food Aust 52:281-295.

Welke JE, Hoeltz M, Dottori HA, Noll IB (2009) Ocorrência de fungos termorresistentes em suco de maçã. Braz J Food Technol 11:78-83.
Yamazaki K, Teduka H, Shinano H (1996) Isolation and Identification of Alicyclobacillus acidoterrestris from acidic beverages. Biosci Biotechnol.Biochem 60:543-545.

Yildiz KA, Coksöyler N (2002) Heat-resistance characteristics of ascospores of Eurotium chevalieri isolated from apricot juice. Mol Nutr Food Res 46:28-30.

Zierler B, Siegmund B, Pfannhauser W (2004) Determination of off-flavour compounds in apple juice by microorganisms using headspace solid phase microextration-gas chromatography-mass spectrometry. Anal Chim Acta 520:3-11.

All the content of the journal, except where otherwise noted, is licensed under a Creative Commons License CC BY-NC. 